\title{
CORRESPONDENCE
}

\section{ISOSPORIASIS IN VENEZUELA: A REPORT OF TWO CASES IN PATIENTS WITH ACQUIRED IMMUNODEFICIENCY SYNDROME.}

In Venezuela, the precise extent of isosporiasis and its effects on human health is unknown. The infection seems to be rare; there is a report from Caracas City in $1942^{1}$. The true prevalence of this coccidiosis in Venezuela probably is underestimated because of the low sensitivity of routine laboratory examinations, used in the evaluation of selected and unselected populations in our country. Nevertheless, stool examinations, using fresh wet mount, iron haematoxylin staining and formalinether concentration, of an estimated 8,000 individuals in our laboratory, have revealed no infections with this coccidium.

Infection rates with Isospora belli as high as $20 \%$ have been reported in patients with acquired immunodeficiency syndrome (AIDS) ${ }^{3}$; in our country there is a single report ${ }^{7}$. Due to the rarity of recorded cases of infection with $\mathbf{I}$. belli in Venezuela, we report two cases of AIDS-related isosporiasis.

The patients were from Zulia State and they had not traveled recently abroad. One of them was a 36-year-old bisexual man from Maracaibo City. $\mathrm{He}$ had a one year-clinical history of malaise, anorexia, weakness, weight loss, and intermittent abdominal pain and diarrhea. The latter became watery and continuous in the last three months. Physical examination revealed generalized lymphadenopathy, oroesophageal candidiasis, signs of muscle wasting, dehydration and weight loss, averaging $18 \mathrm{~kg}$. The other patient was a 27 year-old homosexual man from Cabimas City. He complained about weight loss and intermittent $a b-$ dominal pain ar.d diarrhea in the last 6 months. He required hospitalization, four months before examination, because of fever, vomiting, abdominal pain, diarrhea and dehydration. Physical examination revealed cervical and axillar lymphadenopathy, oral candidiasis and weight loss, averaging $10 \mathrm{~kg}$. Both patients had decreased white blood cell counts $\left(<4.8 \times 10^{3}\right.$ per $\left.\mathrm{mm}^{3}\right)$.

Laboratory diagnosis of $\mathbf{I}$. belli was readily performed with the examination of wet mount preparations. Giardia lambia cysts were also noted in the second case. Faeces incubation in a
$2.5 \%$ potassium dichromate solution revealed the sporulated oocysts. A modified Ziehl-Neelsen carbolfuchsin staining of formalin-ether concentrates $^{5}$ revealed the acid-fast oocysts and a concomitant infection with Cryptosporidium in the first patient.

The first case was lost to follow up before treatment was instituted. The other one was treated with oral trimethoprim $(160 \mathrm{mg})$ and sulfamethoxazole $(800 \mathrm{mg})$ given four times daily for 10 days and then twice daily for 3 weeks. Clinical and parasitological examinations, using fresh wet mounts and formalin-ether concentrates, at 10,30 and 60 days after the beginning of the therapy, revealed resolution of the symptoms and infection. However, three months later watery diarrhea appeared and stool examination revealed the infection. This patient was retreated with a 4-week course of trimethoprim-sulfametoxazole followed by chronic suppressive therapy ${ }^{9}$.

The fact that patients had not traveled recently outside Venezuela suggests that both infections were contracted in the country. Recently, it has been suggested that isosporiasis may be sexually transmitted within the homosexual community $y^{4,6}$. Although our patients had homosexual practices, their infections were probably associated with the classic mechanisms of parasitic transmission since sexual transmission of the coccidium is less likely because a 48-hour period of external incubation is necessary for the oofyst to become infective.

The role of $\mathbf{I}$. belli in the pathogenesis of diarrhea in our patients is uncertain because of the direct enteropathic effects of the human immunodeficiency virus $^{8}$, the concomitant presence of Cryptosporidium in one of them, and the fact that we did not search for pathogenic bacteria and virus. Cases from the literature suggest that chronic diarrhea and weight loss are often found in isosporiasis, as in our patients. Therefore, it seems likely that $\mathbf{I}$. belli was at least partially responsible for the illnesses encountered in these patients. Furthermore, in one of them, diarrhea and infection disappeared with specific therapy and diarrhea reappeared again al ng with the infection. 
It is known that isosporiasis responds promptly to therapy with trimethoprimsulfamethoxazole but is associated with a high rate of relapses ${ }^{2}$. In the present report a similarly prompt response to the treatment and relapse was observed in the treated patient.

Although human isosporiasis appears to be uncommon in Venezuela, there is likely to be an increase in its diagnosis as a cause of diarrhea in immunocompromised individuals paralleling the increase in AIDS.

\section{ACKNOWLEDGEMENTS}

This investigation was supported by CONICIT, Cervecería Modelo and Lagoven.

Instituto de Investigaciones

Clínicas

Universidad del Zulia

Apartado 1151

Maracaibo, Venezuela.

\section{Leonor CHACIN BONILLA}

Yulaicy SANCHEZ DE CHAVEZ

\section{REFERENCES}

1. BRICEÑO ROSSI, A.L. - La coccidiosis en el hombre. Rev. sanid. Asist. soc., 7:449-458, 1942.

2. DEHOVITZ, J.A.; PAPE, J.W.; BONCY, M. \& JOHNSON, W.D. - Clinical manifestations and therapy of Isospora belli infections in patients with the acquired immunodeficiency syndrome. New Engl. J. Med., 315:87$90,1986$.
3. FLOCH, J.J.; LAROCHE, R.; KADENDE, P.; NKURUNZIZA, T. \& MPFIZI, B.- Les parasites, agents etiologiques des diarthées du SIDA. Intérét de l'examen du liquide d' aspiration duodénale. Bull. Soc. Path. exot., 82:316-320, 1989.

4. FORTHAL, D.N. \& GUEST, S.S.- Isospora belli enteritis in three homosexual men. Amer. J. trop. Med. Hyg., 33:1060-1064, 1984.

5. GARCIA, L.S.; BRUCKNER, D.A.; BREWER, T.C. \& SHIMIZU, R.Y.- Techniques for the recovery and identification of Cryptosporidium oocysts from stool specimens. J. clin. Microbiol., 18:185-190, 1983.

6. MA, P.: KAUFMAN, D. \& MONTANA, J.- Isospora belli diartheal infection in homosexual men. AIDS Res, 1:327-338, 1984.

7. MORALES, C.B. \& HEREDIA, W.- Isosporiasis como primera infección oportunista en un paciente con infección por virus de inmunodeficiencia humana. Reporte de un caso. In: JORNADAS CIENTfFICAS DE LA FACULTAD DE MEDICINA, 5., Maracaibo, Universidad del Zulia, 1991. Resumen.p.106.

8. NELSON, J.A.; WILEY, C.A.; REYNOLDS-KOHLER, C.; REESE, C.E.; MARGARETTEN, W. \& LEVY. J.A.Human immunodeficiency virus detected in bowel epithelium from patients with gastrointestinal symptoms. Lancet, 1:259-262, 1988.

9. WHITESIDE, M.E.; BARKIN, J.S.; MAY, R.G.; WEISS, S.D.; FISCHL, M.A. \& MACLEOD, C.L.- Enteric coccidiosis among patients with the acquired immunodeficiency syndrome. Amer. J. trop. Med. Hyg., 33: 10651072, 1984.

Recebido para publicação em 22/10/1992 Aceito para publicação em 6/1/1993 अ: $:$ 